\title{
Service Techniques To Improve Volyball GameS
}

\section{Destriana $^{1 *}$, Destriani ${ }^{2}$, Herri Yusfi ${ }^{3}$}

1,2,3 Universitas Sriwijaya, Palembang, Indonesia

e-mail: destriana@fkip.unsri.ac.id ${ }^{1}$, destriani@fkip.unsri.ac.id ${ }^{2}$, $\underline{\text { herriyusfi@fkip.unsri.ac.id }{ }^{3}}$

\begin{abstract}
The purpose of this research is to produce learning techniques for volleyball service for class IX Junior High School so that by producing new learning techniques, the learning outcomes of student service will be better, this research and development is intended to be a solution to the problem of volleyball game service at junior high school students. This research uses the Research and Development $(R \& D)$ method using the ADDIE development procedure (Analyze, Design, Development, Implementation, and Evaluation). Data was collected through documentation, observation, questionnaires and top service assessment tests. Data analysis was carried out descriptively, qualitatively and quantitatively. The product implementation stage was carried out in class IX.2 totaling 32 students and IX 4 totaling 32 students at Junior High School No 1 Palembang using the development results in the form of 8 top service drill learning techniques that had been declared valid. The learning outcomes of student service in the realm of attitudes, knowledge and skills obtained an average of $88.58 \%$ of students passed the minimum completeness criteria. Based on these learning outcomes, it can be concluded that 8 top service drill learning techniques are said to be effective in learning to serve volleyball games in junior high school students. The findings in this study are that the 8 drill learning techniques developed for top service can be used as a reference for learning techniques that can improve learning outcomes for volleyball service learning.
\end{abstract}

Keywords: Top Service, Result Learning, Volleyball Games.

\section{Introduction}

In the 2013 curriculum, competency standards are developed based on needs, it is hoped that by considering the needs of students, the selected competencies will be more relevant, with regard to content, selection and organizing of content is based on the expected competencies, seen from the system of content delivery or presentation, The 2013 curriculum suggests an integrated and active learning process that can help students develop their skills including thinking skills, knowledge, as well as attitudes and behavior (Fitri et al., 2017; Sundayana, 2015). Teachers must be able to present learning programs with techniques and methods that are attractive and suitable for students. The 2013 curriculum requires good implementation management for successful implementation (Katuuk, 2014; Sari \& Guntur, 2017), there are several strengthening steps that need to be done as a strategy including steps to strengthen implementation planning, main and supporting resources, the learning process in schools, and monitoring and evaluation activities. teachers, school principals, facilities and infrastructure, as well as school climate or culture and the participation of all related parties play a major role in the successful achievement of curriculum implementation.

The role of the teacher, especially the good Sports and Health Physical Education teacher, will be realized if the teacher has initiative, creativity, innovation, and can create learning models and techniques that are pleasing to students. In accordance with the level of development of students, according to fun learning. Physical educators are comprehensive learning that encourages children to have a lot of physical activities, skills, knowledge, and positive attitudes that foster a healthy lifestyle and active play (Dyson, 2014; Sari \& Guntur, 2017). School physical education is very important to be developed by promoting and supporting quality physical education daily activities, to do that, it must convince decision

\footnotetext{
${ }^{*}$ Corresponding author.

Received 22 November 2019; Accepted 16 September 2020; Available online 01 December 2020 (C) 2020 JPI. All Rights Reserved
} 
makers that physical education makes a valuable contribution to the school curriculum (Solmon \& Garn, 2014).

The teacher must be able to present learning with varied and innovative and interactive techniques, models and methods for students. Students will feel happy in the learning process if the teacher uses these tools or media in a form that is simple and easily understood by students, this includes pedagogic competence. Pedagogic competence is the ability to understand students, design and implement learning, evaluate learning outcomes, one of which is to design learning, including understanding the educational foundation for the benefit of learning which includes understanding the foundation of education, determining learning strategies, and compiling learning plans based on the chosen strategy, implementing learning which includes arranging the learning background so that the atmosphere is conducive (Darmadi, 2015).

The teaching and learning process of physical education is essentially centered on a problem, namely how the teacher allows students to have an effective learning process or can achieve results in accordance with the objectives. In the Junior High School Physical Education and Health lesson, one of the teaching materials is the game of volleyball, so what was done in this study was to conduct an initial study of the 2013 curriculum content and to make field observations in several junior high schools to find out more about the existing problems, so that it can look for problems by analyzing the needs in the field.

The results of observations made in junior high schools, especially in the service material for class IX junior high school, namely the lack of facilities and infrastructure, teachers of physical education, sports and health teachers do not use learning media, lack of teaching materials for teachers of physical education, sports and health teachers about volleyball, and the lack of variations in learning techniques in volleyball games. so that children are bored, less interested and have an impact on the results of learning to serve volleyball games. Volleyball is one of the most popular sports in the world due to its immense popularity a lot of research has been done in an effort to better understand the training program needed to develop total body performance for volleyball players (Felicissimo et al., 2012; Marques et al., 2009). Volleyball related to the development of strength performance appears to be very important and is definitely a topic that deserves great attention in physical education in the classroom (Sinelnikov \& Hastie, 2012).

Service is the skill of moving the ball from the back line to the opposing court, many different types of service are used, the most popular type is the top serve (Van Haaren et al., 2016). Top service in the volleyball game is carried out by moving steps, throwing (lifting) the ball, accelerating the hand to the ball, and making further contact, just slide it forward, the body experiences a shift in weight from the back leg to the front leg, when stepping forward, throwing (or in essence lift) the ball directly in front of the shoulder serve high enough to grab the ball then get ready to hit the ball with the right hand.

Previous research examines increasing the results of top service, namely ((Taufik \& Kosasih, 2020) states that the learning method with the application of modified tools has a positive effect in improving student learning achievement, especially volleyball, which is marked by an increase in skill success, another study from (Dupri, 2017) it was found that there was an explosive power of arm muscles and coordination on students' upper serve abilities, the next research was from (Maliki, 2017) developing a top service training model with a play approach for students where the effective results were that the training model was able to improve ball service abilities volleyball, (Sara \& Mashud, 2017) the results of the study showed that students experienced an increase in service skills for volleyball after learning using an inclusive teaching style, based on this previous research there were several ways to improve the results of the volleyball service. ervis above, there has been no research on developing top service drill learning techniques, so this research is intended to develop learning techniques that can improve service results for volleyball games.

This study aims to produce a service learning technique for volleyball that was able to improve learning outcomes for upper service, so the research question was how to develop learning techniques for volleyball service learning that can improve learning outcomes for 
volleyball, so this research develops service learning techniques. the right top so as to improve the learning outcomes of service for volleyball.

\section{Method}

The research method used in this research is development research (Research and Development). Development steps with the ADDIE model. ADDIE stands for analysis, design (planning), development or production (development or production), implementation or delivery (implementation) and evaluations (Destriani et al., 2019). The research steps were to carry out an analysis in the form of collecting literature review information, observing the subject, the subject matter, then carrying out the design stage in the form of defining techniques, formulating objectives, determining the order of techniques, and validating volleyball game experts and sports and health physical education experts with 8 Top service learning techniques as a development draft, the next step is development in the form of oneon-one trials and small group trials. This trial was conducted to obtain the feasibility of learning service techniques for volleyball. This one-on-one test was conducted by 1 teacher of physical education.

The purpose of this evaluation was to get opinions from teachers of teachers of physical education, sports and health subjects on the top service learning techniques, while the small group in this stage was carried out by testing the product on 22 students of grade 9.3 at Junior High School No 1 Palembang, after which revised the main product according to Suggestions from the results of the trial, the next stage is the implementation of 8 top service learning techniques carried out at Junior High School No 1 Palembang in grades 9.2 and 9.4, with 32 students in each class so that there are 64 research subjects. This research was conducted in 2 meetings in each class. This implementation is intended to see the application of learning techniques in the real class so that you can see the weaknesses or strengths of the 8 learning techniques and this research is concluded with the evaluation in this study is intended to review the impact of the development of 8 service learning techniques on volleyball in class students. IX at Junior High School No 1 Palembang, by measuring the achievement of product development goals by measuring what the development goals have been able to achieve, namely improving learning outcomes for volleyball services. The research was carried out at Junior high school No 1 Palembang class IX. With the subjects on the small-scale trial totaling 22 students and at the implementation stage amounting to 64 students. Data was collected through documentation, observation, questionnaires and top service assessment tests. Data analysis was carried out descriptively, qualitatively and quantitatively. Collecting data in the development of learning techniques for these services uses field notes, to record the results of observations of student and teacher behavior during the ongoing learning process, which is carried out during the needs analysis and during the small group trial process and implementation test. , questionnaires as an expert test instrument and service learning outcomes tests in the form of performance tests, observation and knowledge tests. Performed by children to obtain results on the effectiveness test of 8 learning techniques for volleyball service learning.

Data analysis techniques obtained during needs analysis, expert validation, and testing in this development activity are in the form of qualitative data (observations and suggestions / input) and quantitative data (questionnaire results and effectiveness test results). Qualitative data is analyzed during data collection and after completing data collection within a certain period, by summarizing the data to select the main and important things, then presenting the data so that it is easy to understand what happened and planning for further work, then drawing conclusions and verification which is a new finding in the form of a description. The quantitative data from the results of the distribution of the questionnaire were analyzed using descriptive analysis techniques with the percentage of test results for learning services for volleyball. To determine the eligibility category of the 8 top service learning development techniques, a questionnaire was given to be given an assessment by the experts judgment and the teacher in one-on-one test. The questionnaire used in the study used a measurement scale, namely the linkert scale used for experts and teachers 
with 4 choices, after which it could be concluded that the results were feasible and not feasible from the technique.

\section{Results and Discussion}

The results and discussion of research and development obtained the following results;

\section{Analyze}

At this stage, several activities were carried out, namely identifying problems. Based on the results of the observations, it was found that there were problems in the teaching and learning process of sports, especially the top service material in class IX.1 Junior High School No 1 Palembang, the problems faced were the difficulty of students serving up because there were not many variations in teaching teachers, the source of teaching materials and learning media were said. Very little, then analyzed the students, based on the observations of some students when participating in learning activities for the service of volleyball, the students found it difficult to do this movement, so that the desire of students to serve up was reduced. This causes students on average to be less able to perform top services properly, so that the target resource for using the development of learning techniques for service of volleyball is the physical education teacher, which is expected to improve student learning outcomes.

\section{Design}

The initial design developed was 8 top service drill learning techniques, namely learning techniques for top service drills without a ball, learning techniques for learning top service drills for throwing one-handed volleyball, learning techniques for learning top service drills for throwing one-handed volleyball at gradual distances, learning techniques for upper service drill with coordination of volleyball throws and punches, learning techniques for upper service drills with assistance, learning techniques for learning top service drills to hit the wall, learning techniques for learning top service drills with targets, and learning techniques for learning service drills over gradual distance. At the development stage, the stage carried out is expert validation. Validation was carried out by 2 validators, namely the validation of the teachers of physical education, sports and health experts and the volleyball game experts. The results of the validation from experts in physical education, sports and health obtained the average percentage as in table 1.

Table 1.The results of the validation of the top service learning techniques by the physical education teacher

\begin{tabular}{llcl}
\hline No & \multicolumn{1}{c}{ Technique developed } & Percentage & Description \\
\hline 1 & $\begin{array}{l}\text { Technique 1 (learning technique for top serve drill } \\
\text { without ball) }\end{array}$ & $82,5 \%$ & Valid \\
2 & $\begin{array}{l}\text { Technique 2 (learning technique of throwing one- } \\
\text { handed volleyball drill) }\end{array}$ & Valid \\
3 & $\begin{array}{l}\text { Technique 3 (learning technique for drill serve for } \\
\text { throwing a one-handed volleyball at a gradual } \\
\text { distance) }\end{array}$ & Valid \\
\hline $\begin{array}{l}\text { Technique 4 (top service drill learning technique with } \\
\text { volleyball throw and hit coordination }\end{array}$ & $\begin{array}{l}\text { Technique 5 (top service drill learning techniques } \\
\text { with the help of friends) }\end{array}$ & Valid \\
6 & $\begin{array}{l}\text { Technique 6 (learning technique for hitting the top } \\
\text { serve drill to the wall) }\end{array}$ & Valid \\
7 & $\begin{array}{l}\text { Technique 7 (top service drill learning techniques } \\
\text { with the target) }\end{array}$ & $85 \%$ & Valid \\
\hline
\end{tabular}




\begin{tabular}{llcl}
\hline No & \multicolumn{1}{c}{ Technique developed } & Percentage & Description \\
\hline 8 & $\begin{array}{l}\text { Technique 8 (learning technique for drill serve over } \\
\text { gradual distance) }\end{array}$ & $82,5 \%$ & Valid \\
\hline Avarage & $\mathbf{8 2 , 1 9 \%}$ & Valid \\
\hline
\end{tabular}

The results of the research by validators of physical education, sports and health experts from the 8 developed drill learning techniques obtained an average result of $82.19 \%$ so that the product was declared good or feasible. Validation from a volleyball game expert obtained the following results:

Table 2. Validation results of top service learning techniques by volleyball game experts

\begin{tabular}{|c|c|c|c|}
\hline No & Technique developed & Percentage & Description \\
\hline 1 & $\begin{array}{l}\text { Technique } 1 \text { (learning technique for top serve drill } \\
\text { without ball) }\end{array}$ & $80 \%$ & Valid \\
\hline 2 & $\begin{array}{l}\text { Technique } 2 \text { (learning technique of throwing one- } \\
\text { handed volleyball drill) }\end{array}$ & $85 \%$ & Valid \\
\hline 3 & $\begin{array}{l}\text { Technique } 3 \text { (learning technique for drill serve for } \\
\text { throwing a one-handed volleyball at a gradual } \\
\text { distance) }\end{array}$ & $80 \%$ & Valid \\
\hline 4 & $\begin{array}{l}\text { Technique } 4 \text { (top service drill learning technique with } \\
\text { volleyball throw and hit coordination }\end{array}$ & $77,5 \%$ & Valid \\
\hline 5 & $\begin{array}{l}\text { Technique } 5 \text { (top service drill learning techniques } \\
\text { with the help of friends) }\end{array}$ & $85 \%$ & Valid \\
\hline 6 & $\begin{array}{l}\text { Technique } 6 \text { (learning technique for hitting the top } \\
\text { serve drill to the wall) }\end{array}$ & $77,5 \%$ & Valid \\
\hline 7 & $\begin{array}{l}\text { Technique } 7 \text { (top service drill learning techniques } \\
\text { with the target) }\end{array}$ & $82,5 \%$ & Valid \\
\hline \multirow[t]{2}{*}{8} & $\begin{array}{l}\text { Technique } 8 \text { (learning technique for drill serve over } \\
\text { gradual distance) }\end{array}$ & $82,5 \%$ & Valid \\
\hline & Avarage & $81 \%$ & Valid \\
\hline
\end{tabular}

The results of the expert validators from the 8 drill learning techniques developed obtained an average result of $81 \%$ so that the product was declared good or suitable for use in learning top service.

\section{Development}

The development stage is the next stage after the product is declared valid so that it is continued at the development stage, namely activities consisting of one-on-one trials and small group trials of products that have been declared valid, while the results of these trials are as follows. This one-on-one test was carried out on 2 teachers of physical education, sports and health.The purpose of this trial was to teachers of physical education, sports and health get the opinion of the teacher of teachers of physical education, sports and health subjects on the service learning technique for volleyball. One-on-one trials were carried out by giving questionnaires to teachers about developing service drill learning techniques for volleyball games.

The results of one-on-one trials were obtained for each teacher with a percentage of $80 \%$ and $86 \%$. With the results of one to one carried out by teachers of physical education, sports and health, an average percentage of $83 \%$ was obtained for the development of upper service drill learning techniques where these results were included in the "Eligible" (valid) category so that this product could be used as a drill learning technique that could be used as a additional references in learning techniques for volleyball game service for Junior High Schools 
Small group or small group is the step after the product is tested one by one. 8 the development of the upper service drill learning technique was tried out in small groups in class 9.3 with 22 students whose upper service learning had not been completed so that the developed drill learning technique was tried out on these students. With 14 female students and 8 male students.

Development of 8 Top service drill learning techniques were tried out for 2 meetings and evaluated whether the student's learning outcomes had improved. The test used was a top service performance test, the results of the student performance tests were as follows

\section{Top Service Skills Test}

The results of learning for top service were carried out by means of a test of top service skills in the table below, presented data on the results of top service skills as follows

Table 3. Recapitulation of service results for class 9.3

\begin{tabular}{ccccc}
\hline Boy & Girl & Frequency & Percentage (\%) & Information \\
\hline$>27$ & $>23$ & 0 & 0 & Very Good \\
$21-26$ & $18-22$ & 20 & 90,90 & Good \\
$15-20$ & $11-17$ & 2 & 9,10 & Enough \\
$8-14$ & $7-10$ & 0 & 0 & Less \\
$<7$ & $<6$ & 0 & 0 & Very less \\
\hline
\end{tabular}

The results showed that the results of service for students in class 9.3 were in the good category with a percentage of $90.90 \%$. The results of testing the development of service drill learning techniques for small groups obtained good results so that these 8 drill learning techniques were proven to improve service results on ball games for junior high school students, so this research was continued at the implementation stage in the real class.

\section{Implementation}

The implementation of 8 top service drill learning techniques was carried out at Palembang 1 Public Junior High School in grades 9.2 and 9.4. With the test subjects 32 students in each class so that the number of subjects used at the time of implementation amounted to 64 students consisting of male and female students. This research was conducted in 2 meetings in each class. This implementation is intended to see the application of learning techniques in the real class so that you can see the weaknesses or advantages of the 8 top service drill splitting techniques. For the implementation of the implementation, a Learning Implementation Plan is needed which is used by the teacher as a user of the 8 service drill learning techniques.

\section{Evaluation}

The evaluation in this study was intended to revisit the impact of the development of service drill learning techniques on volleyball for class IX students at 1 Palembang State Junior High School, by measuring the achievement of product development goals by measuring what the development goals have been able to achieve, namely improve the results of learning to serve the game of volleyball. Evaluation is carried out in 3 learning domains, namely as follows:

\section{Attitude Test}

Evaluation is carried out by observations made throughout the application of the upper service learning technique. The observation results showed that students in grade 9.2 who passed the minimum sparing criteria were 32 students $(100 \%)$, namely those in the very good category, namely 14 students (43.75\%), the good category was 18 students $(56.25 \%)$. Classically, students are said to be complete, because as many as 32 or $100 \%$ of students are complete in learning top service in the realm of attitude (spiritual and social). 


\section{Top Service Knowledge Test}

The knowledge test was conducted to see students' understanding of learning top services. The results of the research in class 9.2 found that students who passed the minimum sparing criteria in the realm of knowledge were 27 students (84.62\%), namely those in the very good category, namely 5 students $(15.62 \%)$, the good category, namely 22 students $(68.76 \%)$ As for the results obtained in class 9.4 , there were 28 students $(87.5 \%)$ who passed the minimum sparing criteria with 7 students $(21.87 \%)$ in the very good category, and 21 students $(65.63 \%)$ were in the good category so that it was obtained average - The average of the two classes with a percentage of $86.06 \%$ in general students are said to have good learning outcomes.

\section{Student Skills Test}

The results showed that the results of service for class IX.2 students were in the good category or passed the minimum sparing criteria with a percentage of 25 students or $78.13 \%$. The results showed that the service results for class IX.4 students were in the good category or passed the minimum sparing criteria with a percentage of 26 students or $81.25 \%$. The results of the evaluation of 2 classes between class IX.2 and IX.4 obtained an average of $78.13 \%$ and $81.25 \%$ was $79 \%$ of students who passed the minimum sparing criteria.

With the results obtained in each test, it can be calculated the average of each domain, the following results are obtained:

Table 4. Percentage of Student Learning Outcomes

\begin{tabular}{cccccc}
\hline No & Class & Attitude & Knowledge & Skills & $\begin{array}{c}\text { The average } \\
\text { percentage of learning } \\
\text { outcomes }\end{array}$ \\
\hline 1 & 9.2 & $100 \%$ & $84,62 \%$ & $78,13 \%$ & $87,58 \%$ \\
2 & 9.4 & $100 \%$ & $87,5 \%$ & $81,25 \%$ & $89,58 \%$ \\
\hline \multicolumn{5}{c}{ Avarage } & $88,58 \%$ \\
\hline
\end{tabular}

The evaluated domains of the 3 domains are added up, so the average percentage is obtained $88.58 \%$ of students who have passed the minimum sparing criteria. The evaluation carried out concluded that the student learning outcomes that had been carried out got very good results, this was addressed by a percentage of $88.58 \%$ of students who successfully passed the minimum sparing criteria learning service for volleyball games. Data from the results of the evaluation carried out showed that $88.58 \%$ of students succeeded well in learning services for volleyball games using 8 drill learning techniques developed so that it can be concluded that the development product in the form of 8 effective top service drill learning techniques can improve student learning outcomes at volleyball game service material.

\section{Discussion}

The development of top service learning techniques uses the research and development method with ADDIE intructional design. ADDIE stands for Analyze, Design, Development, Implementation and Evaluation. The research begins with conducting a needs analysis by identifying problems in accordance with problems in the skills or knowledge areas of students (Cheung, 2016), besides that the ADDIE analysis phase starts with teaching problems that produce a careful view of the student population and student characteristics (Hess \& Greer, 2016).

The volleyball development model was carried out based on previous research, namely the development in the development of lower-fitting instruments in volleyball games (Daulay \& Daulay, 2018; Pranopik, 2017) from previous research, namely developing smash techniques in volleyball games with research and development research and development methods. This research begins with a needs analysis with observations, the results of 
observations show that in the learning process of volleyball, especially the service material for the problems faced, namely the difficulty of students serving top services, students when participating in learning activities for the service of volleyball, students seem to have difficulties. perform these movements, so that the desire of students to serve up is reduced, this causes students to be less able to serve up properly. Top service is a technique that must be mastered by all players because service is one of the initial attacks that can generate numbers in a game. Jumping serves can be trained using training weights (Marques Junior, 2020). The service results of the volleyball players in the group who were not given pressure through instructions with players who were given pressure on the instructions did not have a significant difference in the results of service accuracy (Wergin et al., 2020). A jumping top serve technique most often used in beach volleyball players. Placement of service directions is more effective in generating points and maintaining the physical performance of players (Medeiros et al., 2014). General jumping service performed by players repeatedly during the match requires high effort and causes physical fatigue to each player (Khal et al., 2020).

The second stage in this research is product design starting from designing goals to be achieved in the learning process, and formulating objectives to be achieved besides that the design / design phase helps to focus and improve the researcher's efforts and create designs where then can build teaching content an interesting and learning experience (Hess \& Greer, 2016).. The goals in this case lead to the development of courage, independence, and motor development of children in the field, including; planning the preparation of learning materials for service learning techniques, planning the use of effective language, planning procedures for implementing top service techniques, planning for experts in their fields, and planning a learning process or daily activity plans so as to assess instructional goals, these instructional objectives are obtained based on the lesson plan so that it is in accordance with the learning provided by sports and health physical education teachers. A review of the material, namely the understanding of the history of the volleyball game, the facilities and infrastructure used, heating and cooling, understanding of top service, basic top service techniques, learning techniques for top service developed, at this planning stage also aims to conduct expert tests where the objectives are want to achieve that is to get the feasibility or validity of learning techniques made with direct assessment of experts, in line with that according to the design stage, it is necessary to create a concept or framework by starting with the construction of this structure means that accurate guidelines are needed for manufacture as defined during The analysis phase includes the course completion schedule, individual lesson arrangements during the course, the form of the teaching strategy and all necessary resources according to a given schedule (Drljača et al., 2017).. This study presents 2 experts in the assessment of the feasibility of learning techniques for serving volleyball, namely; a health and physical education specialist, and a volleyball expert. The results of this research on design resistance found that the learning developed was declared valid or suitable for use based on the results of expert validation with an average of $81 \%$ declared good for learning top service.

The next stage is the development stage, which is an activity consisting of one-onone trials and small group trials of products that have been declared valid. One-on-one trials were carried out on 2 teachers of physical education, sports and health teachers as users, namely by providing a questionnaire on the developed service learning techniques and the results obtained an average percentage of $83 \%$ for the development of top service learning techniques where these results were included in the category "feasible" where The teacher feels that he can use this technique well, then a small-scale trial is conducted on 22 students of grade 9 junior high school. After the small-scale trial, revisions were made based on input from the teacher and observations of students during the implementation of top service learning techniques in the field. To see how well the trial of this technique is carried out tests to see the results of these trials. The test was carried out using a top service skill test which was carried out on students and the results obtained were in the form of a percentage of $90.90 \%$ of students who could perform top service well. 
Implementation is the stage after testing. This implementation is intended to see the application of learning techniques in the real class so that you can see the advantages or disadvantages of the 8 techniques for splitting the above services. For the implementation of the implementation, lesson plan is needed which is used by the teacher as a user of the 8 service learning techniques. The end of this research is at the evaluation stage. The evaluation in this study is intended to revisit the impact of the development of service learning techniques for volleyball in class IX students at Junior High School No 1 Palembang, by measuring the achievement of product development goals by measuring what the development goals have been able to achieve, namely improving learning outcomes. service for volleyball games, besides evaluation or feedback to make it easier for teachers to plan quality, effective, and efficient learning. This technique is applied in 2 meetings in learning. To see the results of learning to serve ball games, a learning evaluation was carried out in all learning domains in terms of attitude, knowledge and skills in top service. For attitudes, the students' attitude observation instruments were carried out during the implementation of learning, knowledge tests with essay tests and skills tests with the top service tests on students, so the cumulative results were obtained in the form of a percentage of $88.58 \%$ of students succeeding or passing the minimum completeness criteria learning services for volleyball games using 8 drill learning techniques developed, this is in line with (Widyastuti \& Susiana, 2019) formative and summative evaluation, formative evaluation is carried out to collect data at each step used for improvement.

This research resulted in the development of learning techniques for upper service drills that can improve student learning outcomes in junior high school. This is in accordance with the results of research (Sari \& Guntur, 2017) there is a significant effect of upper service training using the distance manipulation method on service results for volleyball games, in addition to In another study, the drill method has a significant effect on volleyball playing skills (Yuni, 2017), further research shows that hand-eye coordination has a positive relationship with volleyball service accuracy, then learning under-serve using the drill approach has a greater effect than learning under-serve using a play approach to learning outcomes for lower serve in students, other studies which state that drill has an effect on upper service are (Jaya et al., 2019) training model modification of the hanging ball on the ability of serv is for extracurricular boys when students' volleyball from these studies can be concluded that the drill learning technique can improve the results of learning the service of volleyball.

\section{Conclusions}

Based on the results of the study, it is concluded that the 8 learning techniques of service drill for volleyball can improve the results of top service so that it can be used in learning services for volleyball games. This study resulted in 8 learning techniques of service drill for volleyball learning which were able to improve student learning outcomes in learning services for volleyball games. Based on these results, the implication of this study is that the 8 drill learning techniques developed for top service can be used by teachers of physical education, sports and health in teaching service material for volleyball games. The recommendation of this study is that the top service drill learning technique should be added to the test subject so that the results obtained are even better, besides that for the next research, it can develop other drill learning techniques to improve service learning for volleyball games.

\section{References}

Cheung, L. (2016). Using the ADDIE Model of Instructional Design to Teach Chest Radiograph Interpretation. Journal of Biomedical Education. https://doi.org/10.1155/2016/9502572

Darmadi, H. (2015). Tugas, Peran, Kompetensi, Dan Tanggung Jawab Menjadi Guru Profesional. Jurnal Edukasi.

Daulay, B., \& Daulay, S. S. (2018). Pengembangan Variasi Latihan Kombinasi Passing dan 
Smash dalam Bola Voli. Jurnal Pendidikan Teknologi Dan Kejuruan. https://doi.org/10.24114/jptk.v20i1.11040

Destriani, D., Destriana, D., Switri, E., \& Yusfi, H. (2019). The development of volleyball games learning for students. Jurnal SPORTIF: Jurnal Penelitian Pembelajaran. https://doi.org/10.29407/js_unpgri.v5i1.12605

Drljača, D., Latinović, B., Stanković, Ž., \& Cvetković, D. (2017). ADDIE Model for Development of E-Courses. https://doi.org/10.15308/sinteza-2017-242-247

Dupri, D. (2017). Hubungan Explosive Power Otot Lengan Dan Koordinasi Mata-Tangan Terhadap Kemampuan Servis Atas Atlet Bolavoli Kuansing Kabupaten Kuantan Singingi. Journal Sport Area. https://doi.org/10.25299/sportarea.2016.vol1(2).385

Dyson, B. (2014). Quality physical education: A commentary on effective physical education teaching. In Research Quarterly for Exercise and Sport. https://doi.org/10.1080/02701367.2014.904155

Felicissimo, C. T., Dantas, J. L., Moura, M. L., \& De Moraes, A. C. (2012). Respostas neuromusculares dos membros inferiores durante protocolo intermitente de saltos verticais em voleibolistas. Motriz. Revista de Educacao Fisica. https://doi.org/10.1590/s1980-65742012000100016

Fitri, Saparahayuningsih, \& Agustriana. (2017). Perencanaan Pembelajaran Kurikulum 2013 Pendidikan Anak Usia Dini. Jurnal IImiah Potensia, 2(1). https://doi.org/https://doi.org/10.33369/jip.2.1.1-13

Hess, A. K. N., \& Greer, K. (2016). Designing for engagement: Using the ADDIE model to integrate high-impact practices into an online information literacy course. Communications in Information Literacy. https://doi.org/10.15760/comminfolit.2016.10.2.27

Jaya, H., Insanistyo, B., Sofino, S., \& Defliyanto, D. (2019). Pengaruh Model Latihan Modifikasi Bola Gantung Terhadap Kemampuan Servis Atas Putra Ekstrakurikuler Smkn 3 Kota Bengkulu. Kinestetik. https://doi.org/10.33369/jk.v2i2.6494

Katuuk, D. A. (2014). Manajemen Implementasi Kurikulum: Strategi Penguatanimplementasi Kurikulum 2013. Jurnal Cakrawala Pendidikan. https://doi.org/10.21831/cp.v111.1858

Khal, K. M., Moore, S. D., Pryor, J. L., \& Singh, B. (2020). Changes In Infraspinatus And Lower Trapezius Activation In Volleyball Players Following Repetitive Serves. International Journal of Sports Physical Therapy. https://doi.org/10.26603/ijspt20200196

Maliki, T. S. (2017). Mengembangkan Model Latihan Servis Atas Bola Voli. Jurnal Siliwangi.

Marques Junior, N. K. (2020). Specific periodization for the volleyball : the importance of the residual training effects. MOJ Sports Medicine. https://doi.org/10.15406/mojsm.2020.04.00086

Marques, M. C., Van Den Tillaar, R., Gabbett, T. J., Reis, V. M., \& González-Badillo, J. J. (2009). Physical fitness qualities of professional volleyball players: Determination of positional differences. Journal of Strength and Conditioning Research. https://doi.org/10.1519/JSC.0b013e31819b78c4

Medeiros, A. I. A., Mesquita, I. M., Marcelino, R. O., \& Palao, J. M. (2014). Effects of technique, age and player's role on serve and attack efficacy in high level beach volleyball players. International Journal of Performance Analysis in Sport. https://doi.org/10.1080/24748668.2014.11868751

Pranopik, M. R. (2017). Pengembangan Variasi Latihan Smash Bola Voli. Jurnal Prestasi. https://doi.org/10.24114/jp.v1i1.6495 
SARA, I. A., \& MASHUD, M. (2017). Penerapan Pembelajaran Servis Atas Bolavoli Menggunakan Gaya Mengajar Inklusi Pada Siswa Kelas X Di Smk Grafika Pgri-Pakis. Multilateral Jurnal Pendidikan Jasmani Dan Olahraga. https://doi.org/10.20527/multilateral.v15i2.2743

Sari, Y. B. C., \& Guntur, G. (2017). Pengaruh metode latihan dan koordinasi mata-tangan terhadap hasil keterampilan servis atas bola voli. Jurnal Keolahragaan. https://doi.org/10.21831/jk.v5i1.12773

Sinelnikov, O. A., \& Hastie, P. A. (2012). College students' perspectives, goals, and strategies in sport education. Research Quarterly for Exercise and Sport. https://doi.org/10.1080/02701367.2012.10599855

Solmon, M. A., \& Garn, A. C. (2014). Effective teaching in physical education: Using transportation metaphors to assess our status and drive our future. In Research Quarterly for Exercise and Sport. https://doi.org/10.1080/02701367.2013.872530

Sundayana, W. (2015). Readiness and competence of senior high school english teachers to implement curriculum 2013. Indonesian Journal of Applied Linguistics. https://doi.org/10.17509/ijal.v5i1.828

Taufik, M. S., \& Kosasih, A. H. (2020). Meningkatkan Keterampilan Pasing Atas Bolavoli Melalui Penerapan Modifikasi Alat. Multilateral Jurnal Pendidikan Jasmani Dan Olahraga. https://doi.org/10.20527/multilateral.v19i1.8308

Van Haaren, J., Shitrit, H. Ben, Davis, J., \& Fua, P. (2016). Analyzing volleyball match data from the 2014 world championships using machine learning techniques. Proceedings of the ACM SIGKDD International Conference on Knowledge Discovery and Data Mining. https://doi.org/10.1145/2939672.2939725

Wergin, V. V., Beckmann, J., Gröpel, P., \& Mesagno, C. (2020). Investigating cumulative effects of preperformance routine interventions in beach volleyball serving. PLoS ONE. https://doi.org/10.1371/journal.pone.0228012

Widyastuti, E., \& Susiana. (2019). Using the ADDIE model to develop learning material for actuarial mathematics. Journal of Physics: Conference Series. https://doi.org/10.1088/1742-6596/1188/1/012052

Yuni, A. (2017). Pengaruh Metode Drill dan Metode Bermain Terhadap Keterampilan Bermain Bola Voli Mini (Studi Eksperimen Pada Siswa SD Negeri 14 Kampung Jambak Kecamatan Koto Tangah Kota Padang). Al Ibtida: Jurnal Pendidikan Guru MI. https://doi.org/http://dx.doi.org/10.24235/al.ibtida.snj.v4i1.1276 Al 